\title{
Demographic and Geographic Distribution of Sickle Cell Disease in Gondia District of Central India; A Hospital Based Study.
}

\author{
Dr. Pallavi Janrao Kamble ${ }^{1}$, Dr. Sankalp Kumar Tripathi ${ }^{2 *}$
}

${ }^{1}$ Assistant Professor, Department of Biochemistry, Government Medical College, Gondia, Maharashtra, India ${ }^{2}$ Assistant Professor, Department of Biochemistry, ABV Government Medical College, Vidisha, Madhya Pradesh, India

Corresponding author: Dr. Sankalp Kumar Tripathi, Assistant Professor, ABV Government medical college, Vidisha, Madhya Pradesh, India. Mob.+91-7276384613, Mail ID: drskt20@gmail.com

Address: Flat 304 Block 7 Govt. Medical College campus, Vidisha-464001, Madhya Pradesh, India.

\section{ABSTRACT}

Background: Sickle cell disease is prevalent in central India. Gondia district is located in the Vidarbh region of Maharashtra of central India. Objective of this study is to find the geographic (block level and primary health center level) and demographic (age, sex, caste, sub-caste) distribution of sickle cell carriers and cases which presented to the hospitals for last 10 years.

Methods : All the symptomatic patients visiting five hospitals of Gondia were tested by solubility test. Those found positive in solubility test were tested by hemoglobin electrophoresis. Results were categorized into sickle cell carriers/traits (AS pattern) and sickle cell cases (SS pattern).

\section{RESULTS:}

Total 1318567 patients were tested by solubility test and 18152 were found positive. These underwent hemoglobin electrophoresis and revealed 11209 carriers/traits and 1088 cases. More females were carriers and more males were cases. Most of the patients presented were between 11-20 years of age. Unmarried cases were significantly higher than unmarried carriers. With around $20 \%$ of disease burden, Gondia block have highest number of patients. Schedule casts have highest number of patients followed by other backward classes and schedule tribes.

Conclusion: Maximum number of sickle cell patients was from Gondia block followed by Arjuni Morgaon and Sadak Arjuni block. Sickle cell disease is most prevalent in Mahar sub-caste of SC, Gond, Halbi sub-caste of ST and Kunbi, Mali, Teli, Kalar sub-caste of OBC. Public health authorities need to focus more in these blocks and sub-castes to promote awareness and improve quality of life.

Keywords: sickle cell, gondia, caste.

\section{Introduction}

Sickle cell disease has an autosomal recessive pattern of inheritance [1]. The gene defect is a single nucleotide mutation of the $ß$-globin gene, which results in glutamic acid being substituted by valine at position 6 . Under low oxygen concentration, $\mathrm{HbS}$ polymerizes and forms fibrous precipitates because the deoxy form of hemoglobin exposes a hydrophobic patch on the protein ${ }^{[2]}$. In people heterozygous for $\mathrm{HbS}$ (carriers/ traits), the polymerization problems are minor because the normal allele is able to produce half of the hemoglobin. In people homozygous for HbS (cases), the presence of long-chain polymers of HbS distorts the shape of the red blood cell and makes it fragile and susceptible to break within capillaries. Carriers have symptoms only if they are deprived of oxygen (for example, while climbing a mountain) or while severely dehydrated. The allele responsible for sickle cell anemia is present on the short arm of chromosome $11^{[3]}$.

Hemolysis is the actual cause of anemia. Healthy red blood cells function for 90-120 days, but sickled red blood cells last only for 10-20 days ${ }^{[4]}$. Clinical signs usually begin in early childhood and the severity of symptoms varies from person to person. Sickle cell disease may lead to various acute and chronic complications such as anemia, vaso-occlusive pain crises, risk for pneumococcal infections, acute chest syndrome, stroke and organ failure with high morbidity and mortality. Infection, dehydration, oxidative stress and acidosis promotes sickling ${ }^{[5]}$.

Sickle cell anemia is prevalent among people in malaria endemic areas such as Mediterranean, Africa, India, and the Middle East due to adaptive advantage of heterozygote ${ }^{[6]}$. In India, the disease is prevalent among tribal populations in Maharashtra, Madhya Pradesh, Chhattisgarh, south Gujarat and western Odisha with a smaller focus in the southern region in Andhra Pradesh, northern Tamil Nadu, Karnataka and Kerala. It is also prevalent in some of the non-tribal populations, scheduled castes and other backward classes mainly in central India ${ }^{[7,8]}$. It is estimated that India has $50 \%$ of the world's sickle cell patients. While sickle cell is prevalent in many ethnic groups, the highest prevalence appears to be in scheduled castes, scheduled tribes, and other backward classes ${ }^{\left[{ }^{9}\right.}$. In India, the prevalence of sickle cell carriers in different tribes varies from 0-35 percent ${ }^{[10]}$.

The sickle cell gene is widespread in all the eastern districts (vidarbha region) of Maharashtra, Satpura range and in some parts of Marathawada. In Maharashtra, a study reported prevalence of disease from $1.9 \%$ to $33.5 \%$ in different 
communities ${ }^{[11]}$. In central India, the sickle cell anemia incidence was found highest in the scheduled caste group(1:50) ${ }^{[12]}$. Another study was the first to report the disease in vidarbha region of Maharashtra showing prevalence from $9.4 \%$ to $22.2 \%$ in non-tribal population ${ }^{[13]}$. Other study reported prevalence of $5.5 \%$ from few villages of Wardha ${ }^{[14]}$. In a study performed in Vidarbh region, 35,636 people were screened, in which 5466 were identified with sickle cell trait and 1010 were found to have sickle cell disease. This study also showed sickle cell trait prevalence of $13.0 \%$ in the SC, $12.0 \%$ in the ST and $3.4 \%$ in the $\mathrm{OBC}$ population ${ }^{[15]}$. Gondia district is in the Vidarbh region of Maharashtra. As per 2011 census, total population of Gondia district is 1322507 and SC, ST population is 355484,309822 respectively. In this study, we tried to figure out the geographic and demographic prevalence of sickle cell trait and sickle cell disease in Gondia district.

\section{MATERIAL AND METHODS}

This is retrospective descriptional study based on records of five hospitals namely KTS District general hospital, Bai Gangabai womens hospital, Rural hospital of Rajegaon, Deori and Amgaon for last 10 years i.e. from april 2009 to december 2019. As this region has high prevalence of sickle cell disease, an extensive screening of all the symptomatic patients visiting these five hospitals was done for sickle cell trait and disease under sickle cell control programme run by government of Maharashtra. All the patients presenting with anemia, intermittent jaundice, joint pains, painful vaso-occlusive crisis and splenomegaly were tested by solubility test. A mixture of $\mathrm{RBC}$ containing $\mathrm{HbS}$ in a reducing solution (such as sodium dithionite) gives a turbid appearance, whereas normal $\mathrm{Hb}$ gives a clear solution. $\mathrm{Hb}$ Electrophoresis of solubility test positive patients was done. Results were categorized into Normal (AA) Trait (AS) and disease (SS). Based on available records results were grouped into geographic prevalence i.e. Blocks, Primary health center (PHC) and demographic prevalence i.e. Age, Sex, Caste, marital status.

\section{RESULTS}

Table 1: Number of Tests and Results

\begin{tabular}{|c|c|}
\hline Total Solubility test performed & 1318567 \\
\hline Positive solubility tests & 18152 \\
\hline Total Hb Electrophoresis performed & 18152 \\
\hline Normal (HbAA) & $5855(32.25 \%)$ \\
\hline Carrier (HbAS) & $11209(61.75 \%)$ \\
\hline Cases (HbSS) & $1088(5.99 \%)$ \\
\hline
\end{tabular}

Table 2: Gender distribution

\begin{tabular}{|c|c|c|c|}
\hline Carrier & Male & 4723 & $42.14 \%$ \\
\hline & Female & 6486 & $57.86 \%$ \\
\hline & Total & 11209 & \\
\hline & & & \\
\hline Cases & Male & 561 & $51.56 \%$ \\
\hline & Female & 527 & $48.44 \%$ \\
\hline & Total & 1088 & \\
\hline
\end{tabular}

Table 3: Age distribution

\begin{tabular}{|c|c|c|c|c|}
\hline Age & Carrier & & Cases & \\
\hline $0-10$ yrs. & 2114 & $18.85 \%$ & 298 & $27.38 \%$ \\
\hline $11-20$ yrs. & 4230 & $37.73 \%$ & 381 & $35.01 \%$ \\
\hline $21-30$ yrs. & 2685 & $23.95 \%$ & 267 & $24.54 \%$ \\
\hline $31-40$ yrs. & 1407 & $12.55 \%$ & 101 & $9.28 \%$ \\
\hline $41-50$ yrs & 511 & $4.55 \%$ & 26 & $2.38 \%$ \\
\hline $51-60$ yrs. & 198 & $1.76 \%$ & 12 & $1.1 \%$ \\
\hline$>60$ yrs. & 64 & $0.57 \%$ & 3 & $0.27 \%$ \\
\hline & 11209 & & 1088 & \\
\hline
\end{tabular}

Table 4: Marital status

\begin{tabular}{|c|c|c|c|}
\hline & Married & Unmarried & Total \\
\hline Carrier & $4742(42.3 \%)$ & $6467(57.69 \%)$ & 11209 \\
\hline Cases & $290(26.65 \%)$ & $798(73.34 \%)$ & 1088 \\
\hline
\end{tabular}

Table 5: Geographic distribution according to Blocks and PHC

\begin{tabular}{|c|c|c|c|c|}
\hline Blocks & PHC & \multicolumn{2}{|c|}{ Controls } & Total (\%) \\
\hline \multirow{4}{*}{ Amgaon } & Bangaon & 296 & 16 & \multirow{4}{*}{$\begin{array}{c}135 \\
(12.4 \%)\end{array}$} \\
\hline & Kalimati & 341 & 55 & \\
\hline & Tigaon & 218 & 28 & \\
\hline & Thana & 181 & 36 & \\
\hline \multirow{5}{*}{ Gondia } & Bhanpur & 312 & 31 & \multirow{5}{*}{$\begin{array}{c}243 \\
(22.33 \%)\end{array}$} \\
\hline & Ekodi & 223 & 17 & \\
\hline & Rawanwadi & 417 & 76 & \\
\hline & Kamtha & 310 & 37 & \\
\hline & Dawaniwada & 201 & 18 & \\
\hline
\end{tabular}




\section{Pallavi Janrao Kamble et al}

\begin{tabular}{|c|c|c|c|c|c|}
\hline & Dasgaon & 254 & & 22 & \\
\hline & Morwahi & 226 & & 21 & \\
\hline & Kati & 235 & & 21 & \\
\hline & kawarabhandh & 213 & & 21 & \\
\hline Salekasa & Satgaon & 303 & 913 & 36 & \\
\hline & Darekasa & 288 & (8.14\%) & 39 & (9.83\%) \\
\hline & Bijepar & 109 & & 11 & \\
\hline & Channa Bhakti & 447 & & 40 & \\
\hline & Dhabepawani & 353 & & 35 & \\
\hline $\begin{array}{l}\text { Arjuni } \\
\text { Morgaon }\end{array}$ & Korambhitola & 397 & 1997 & 28 & 173 \\
\hline & Mahagaon & 304 & (17.81\%) & 24 & (15.9\%) \\
\hline & Gothangaon & 249 & & 29 & \\
\hline & Keshori & 247 & & 17 & \\
\hline & Pandhari & 799 & & 43 & \\
\hline Sadak / & Dawwa & 278 & 1921 & 22 & 156 \\
\hline Arjuni & Shenda & 444 & (17.13\%) & 38 & $(14.33 \%)$ \\
\hline & Soundad & 400 & & 53 & \\
\hline & Mulla & 399 & & 68 & \\
\hline & Kakodi & 324 & 1261 & 17 & \\
\hline (2) & Futana & 378 & (11.24\%) & 19 & (10.66\%) \\
\hline & Ghonadi & 160 & & 12 & \\
\hline & Soni & 265 & & 11 & \\
\hline & Chopa & 253 & & 15 & \\
\hline Goregaon & Kawalewada & 159 & 1346 & 16 & 85 \\
\hline & Kurhadi & 375 & (12\%) & 34 & (7.81\%) \\
\hline & $\begin{array}{c}\text { Tilli } \\
\text { Mohagaon }\end{array}$ & 294 & & 9 & \\
\hline & Indora & 129 & & 13 & \\
\hline Tiroda & Mundikota & 116 & 557 & 21 & 73 \\
\hline & Wadegaon & 187 & (4.96\%) & 28 & $(6.1 \%)$ \\
\hline & Sukadi & 125 & & 11 & \\
\hline
\end{tabular}

www. pimr.org.in

Table 6: Caste distribution

\begin{tabular}{|c|c|c|c|}
\hline Carrier & SC & 4556 & $40.64 \%$ \\
\hline & ST & 2757 & $24.59 \%$ \\
\hline & OBC & 3552 & $31.68 \%$ \\
\hline & Others & 344 & $3.06 \%$ \\
\hline Cases & Total & 11209 & \\
\hline & SC & 553 & $50.82 \%$ \\
\hline & ST & 179 & $16.45 \%$ \\
\hline & OBC & 283 & $26.01 \%$ \\
\hline & Others & 73 & $6.7 \%$ \\
\hline & Total & $\mathbf{1 0 8 8}$ & \\
\hline
\end{tabular}

Table 7: Subcaste distribution

\begin{tabular}{|c|c|c|c|c|c|}
\hline Caste & Subcaste & Carrier & & Cases & \\
\hline & Mahar & 4352 & $95.52 \%$ & 537 & $97.1 \%$ \\
\hline & Chambhar & 126 & $2.76 \%$ & 11 & $1.98 \%$ \\
\hline & Holiyaa & 78 & $1.71 \%$ & 5 & $0.9 \%$ \\
\hline & Total & 4556 & & 553 & \\
\hline ST & Gond & 1530 & $55.49 \%$ & 131 & $73.18 \%$ \\
\hline & Halbi & 859 & $31.15 \%$ & 35 & $19.55 \%$ \\
\hline & Gowari & 346 & $12.54 \%$ & 13 & $7.26 \%$ \\
\hline & Nagarchi & 8 & $0.29 \%$ & 0 & $0 \%$ \\
\hline & Bhill & 7 & $0.25 \%$ & 0 & $0 \%$ \\
\hline & Binjhwar & 7 & $0.25 \%$ & 0 & $0 \%$ \\
\hline OBC & Total & 2757 & & 179 & \\
\hline & Kunbi & 1238 & $34.85 \%$ & 111 & $39.22 \%$ \\
\hline & Mali & 561 & $15.79 \%$ & 34 & $12.01 \%$ \\
\hline & Teli & 547 & $15.39 \%$ & 55 & $19.43 \%$ \\
\hline & Kalar & 489 & $13.76 \%$ & 37 & $13.07 \%$ \\
\hline & Dhiwar & 243 & $6.84 \%$ & 19 & $6.71 \%$ \\
\hline & Powar & 131 & $3.68 \%$ & 8 & $2.82 \%$ \\
\hline & Lohar & 95 & $2.67 \%$ & 6 & $2.12 \%$ \\
\hline & Lodhi & 75 & $2.11 \%$ & 4 & $1.41 \%$ \\
\hline
\end{tabular}


Pallavi Janrao Kamble et al

\begin{tabular}{|c|c|c|c|c|c|}
\hline & Sonar & 68 & $1.91 \%$ & 5 & $1.76 \%$ \\
\hline & Kohali & 57 & $1.6 \%$ & 2 & $0.7 \%$ \\
\hline & Muslim & 34 & $0.95 \%$ & 2 & $0.7 \%$ \\
\hline & Koshti & 3 & $0.08 \%$ & 0 & $0 \%$ \\
\hline & Kumbhar & 5 & $0.14 \%$ & 0 & $0 \%$ \\
\hline & Ahir & 3 & $0.08 \%$ & 0 & $0 \%$ \\
\hline & Thakur & 3 & $0.08 \%$ & 0 & $0 \%$ \\
\hline & Total & $\mathbf{3 5 5 2}$ & & $\mathbf{2 8 3}$ & \\
\hline
\end{tabular}

\section{DISCUSSION}

Total 1318567 patients were tested for solubility test in during last 10 years and 18152 patients were tested positive. All these underwent $\mathrm{Hb}$ electrophoresis in which $5.99 \%$ diagnosed as sickle cell cases, $61.75 \%$ as sickle cell trait or carrier and $32.25 \%$ as normal (Table:1). Female (57.86\%) dominated as carrier while male $(51.56 \%)$ dominated as cases (Table:2). Most of the cases and carriers were under 30 years of age with majority in between $11-20$ years. Significantly more cases were found below 10 years as compared to carriers (Table:3). This shows early appearance of clinical symptoms in homozygotes as compared to the traits. More unmarried cases (73.34\%) were reported as compared to unmarried carriers (57.69\%) and it was statistically significant (Table:4). This is due to higher number of homozygotes below 10 years of age as compared to carriers. Problem in marriage may also contribute to this due to more severe symptoms.

Gondia district has 8 Blocks which further have 39 primary health centers. We observed that maximum number of patients was from Gondia block followed by Arjuni Morgaon and Sadak Arjuni block. Amgaon, Deori and Goregaon have approximately equal distribution followed by Salekasa and Tiroda (Table:5).

Sickle cell disease was found to be most prevalent in schedule casts with $40.64 \%$ of carrier and $50.82 \%$ of cases (Table:6). Among schedule casts Mahar sub-caste predominates with more than $95 \%$ of cases and carriers (Table:7). Schedule tribe population contributes to $24.59 \%$ of carriers and $16.45 \%$ of cases. Gond sub-caste contribute more than half of ST carriers and more than 2/3rd of ST cases followed by sub-caste Halbi and Gowari. OBC population contributes $31.68 \%$ of carriers and $26.01 \%$ of cases with major contribution from sub-caste Kunbi (more than 1/3rd of OBC cases and carriers) followed by sub-caste Mali, Teli, Kalar, Dhiwar, Powar, Lohar, Lodhi, Sonar etc. www. pimr.org.in

\section{CONCLUSION}

Maximum number of Sickle cell patients was from Gondia block followed by Arjuni Morgaon and Sadak Arjuni block. Schedule cast (Mahar sub-caste) predominate the total number of sickle cell traits and cases followed by OBC (Kunbi sub-caste) and ST (Gond sub-caste). As far as sub-castes are concerned, Mahar is a way ahead in number of cases and carriers followed by Gond, Kunbi, Halbi, Mali, Teli, Kalar, Gowari, Dhiwar etc. Public health authorities need to focus more in these blocks and subcastes to promote awareness and improve quality of life.

\section{LIMITATION}

This is retrospective descriptional study based on hospital records of last 10 years and it does not give clear image of community prevalence because people come to the hospital when they are symptomatic. Real prevalence of the disease would be more as many people will be asymptomatic also. More community based extensive screening programmes are needed to get the real picture.

\section{DECLARATIONS}

Funding: No funding received

Conflict of interest: None declared

Ethical approval: Not required

\section{REFERENCES}

1. Sankaran VG. Orkin SH. The switch from fetal to adult hemoglobin. Cold Spring Harb Perspect Med. 2013;1(3):011643

2. Odièvre MH. Verger E. Silva-Pinto AC. Elion J. Pathophysiological insights in sickle cell disease. Indian J Med Res. 2011;134:532-7

3. Allison AC. Genetic control of resistance to human malaria. Curr Opin Immunol. 2009;21:499-505

4. Lesi FE. Bassey EE. Family study in sickle cell disease in Nigeria. J Biosoc Sci. 1972;4:307-13

5. Yawn BP. Buchanan GR. Afenyi AN et al. Management of Sickle Cell Disease: Summary of the 2014 Evidence-Based Report by Expert Panel Members. JAMA. 2014;312:103348

6. Kwiatkowski DP. How malaria has affected the human genome and what human genetics can teach us about malaria. Am J Hum Genet. 2005;77:171-92

7. Urade BP. Incidence of sickle cell anemia and thalassemia in Central India. Open J. Blood Dis. 2012;2:71-80

8. Colah R. Mukherjee M. Ghosh K. Sickle cell disease in India. Curr. Opin. Hematol. 2014;21:215-23

9. Kate SL. Lingojwar DP. Epidemiology of Sickle Cell Disorder in the State of Maharashtra. Inter J of Hum Genet. 2002;2(3):161-7 
10. Colah RB. Mukherjee MB. Martin S. Ghosh K. Sickle cell disease in tribal populations in India. Indian J Med Res. 2015;141:509-15

11. Bankar MP. Kate SL. Mokashi GD. Phadke MA. Distribution of sickle cell haemoglobin amongst different tribal groups in Maharashtra. Ind J Haematol. 1984;2:224

12. Jain DL. Sarathi V. Upadhye D. Gulhane R. Nadkarni AH. Ghosh K et al. Newborn Screening Shows a High Incidence of Sickle Cell Anemia in Central India. Hemoglobin. 2012;36:316-22

13. Shukla RM. Solanki BR. Sickle Cell Trait in India. Lancet. 1985; 1:297-8

14. Deshmukh P. Garg BS. Garg N. Prajapati NC. Bharambe MS. Prevalence of sickle cell disorders in rural Wardha. Indian J Community Med. 2006;31:26-7

15. Shrikhande AV. Arjunan A. Agarwal A. Dani A. Tijare J. Krishnamurti L. Prevalence of the BS gene among scheduled castes, scheduled tribes and other backward class groups in central India. Hemoglobin. 2014;38:230-5

How to cite this article : Kamble P,Tripathi S. Demographic and Geographic Distribution of Sickle Cell Disease in Gondia District of Central India; A Hospital Based Study. Perspectives in Medical Research 2020; 8(1):59-63

Sources of Support: Nil,Conflict of interest:None declared. 